\title{
The Effect of Interest Rate Differentials on Exchange Rate Volatility of East African Community Currencies
}

\author{
Désiré Ntirabampa, MSc Finance Student \\ Dr. Cyrus Iraya, Lecturer
}

Department of Finance and Accounting, University of Nairobi, Kenya

Doi:10.19044/esj.2019.v15n19p203 URL:http://dx.doi.org/10.19044/esj.2019.v15n19p203

\begin{abstract}
The study sought to test the effect of interest rate differentials on the exchange rate volatility of East African Community currencies. It used secondary data collected from Central Bank of Kenya, Bank of Uganda, Bank of Tanzania, Bank of the Republic of Burundi, National Bank of Rwanda and the IMF e-Library. A panel data model was used to regress average monthly exchange rates, interest rate differentials, inflation rate differentials and relative current account balances for a period starting from January 2013 to December 2017. Findings from the fixed-effects model showed that $98.8 \%$ of the variation in the exchange rate is explained by the three independent variables. Interest differential was the main independent variable with a coefficient's value of 0.0274. This means that in East African Community an increase by 1 point in interest rate differential leads to the depreciation of home currency by 0.0274 points. The study also found that the relative current account balance contributes also to the home currency depreciation with a coefficient's value of 0.000052 . However, the study could not be able to find the expected results for inflation differential as it has a negative coefficient's value (-0.0075). This contradicts the economic theory on inflation differential and may due to other variables that were not included in the model but can be with great importance in the explanation of exchange rate movement. The study further suggested that more research can be carried out to bring forth more knowledge to the pool of literature on the relationship between interest rate differential and exchange rate volatility in the region.
\end{abstract}

Keywords: Interest Rate Differential, Exchange Rate Volatility, East African Community Currencies, Relative Current Account, Inflation Differential 


\section{Introduction}

In international markets, there is a close connection between interest rate differentials and exchange rate volatility because higher interest rates in any country can reduce the money demand and cause the rise in price level, which in turn can lead to the exchange rate depreciation (Sargent \& Wallace, 1981; Furman \& Stiglitz, 1998). This connection is mainly explained the theory of international Fisher Effect which says that the expected change in exchange rates is given by the difference in nominal interest rates across countries (Fisher, 1930).

There are several studies done on the relationship between interest rate differentials and exchange rates volatility by putting together inflation, interest and exchange rate as three variables that can move in time when outside interventions to the monetary markets are limited. Their findings prove that the two variables are related. But their conclusions are mixed and not definite as for some studies the relationship is negative in short terms and positive in long terms.

For example, Hacker et al. (2010) utilized annual data for the period of 1993 to 2009 to investigate the relationship between the spot exchange rate and the interest rate differential for seven pairs of countries, with a small country, Sweden, included in each of the cases. The methodology used was Wavelet Approach which consists of grouping time-series into various scales and helps to analyze them on a scale-by-scale basis. They used three-month interest rates, with monthly and quarterly spot exchange rates against the Swedish krona (SEK) of five major currencies (USD, JPY, Euro, GBP and SWF) and two other currencies (NOK, and KRW). Findings demonstrated that the relationship between the two variables is negative in the short-run periods, at wavelet scales of a half year or less, and positive in the long-run periods more than one year.

Ersan (2008) analyzed the effect of change in interest rates on the exchange rate between Turkey and the G-5 countries of United States, United Kingdom, Japan, France and Germany on 3 sub-periods of time. The first period includes US, UK and Japan, between January 1985 and December 2007. The second one considers a group of the US, Germany, France, japan and the UK, between January 1985 and December 1998; while the third period includes Turkey, Japan, US, UK, Germany and France, between January 1999 and December 2007. He used Co-Integration and DSUR (Dynamic Seemingly Unrelated Regression) Frameworks, with monthly interest and exchange rate values. Results showed that nominal interest rates explain exchange rate volatility for equations which include Turkey during the 1999-2007 periods. However, between 1985 and 1998, findings are favorable only between France and Germany. 
The general conclusion was that the exchange rate volatility is caused by other additional factors besides nominal interest rate differentials.

Stephen (2014) did a study on the effect of interest rate differential on the foreign exchange rate in East African forex market. His objective was to verify on whether interest rate parity and PPP models hold among EAC three countries such as Kenya, Uganda and Tanzania. The methodology used was to apply a multiple linear regression analysis on monthly real exchange rates as dependent variable, and real interest rate differentials, relative inflation rate, relative deficit/surplus rate as independent variables, all the information for a period starting from January 2009 to July 2014. The regression results revealed an unclear relationship between real interest differentials and real exchange rates in the East African forex market because real interest differentials contributed for only $10 \%$ in the variation of the real exchange rates.

Emil (2002) carried a study on the empirical investigation of the International Fisher Effect, where the main objective was to test the probability that nominal interest differentials can offset volatility in exchange rates in the long term, between US (as the home country) and five countries that are Canada, UK, Sweden, Germany and Japan. The regression method used was Ordinary Least Square which was applied on quarterly nominal interest differentials of the five countries relative to US interest rates, and quarterly change in exchange rates for the same countries relative to the USD, all the information between 1993 and 2000. The results showed that change in exchange rate is explained by nominal interest differentials only between United States and Japan.

Lungu and Johannes (2014) evaluated the relationship between interest rate and exchange rate in Namibia. They applied a Vector Autoregressive (VAR) approach to quarterly data all information between 1993 and 2012. Their findings proved that the relation between exchange rates and interest rates is not systematically clear as all variables of the study were not cointegrated. Therefore, the variance decomposition disclosed moreover that the errors in the forecast of the rate of exchange and rate of interest are dominated by itself and an insignificant percentage is also assigned to other variables.

Francisco and Razzak (1999) evaluated the long-run relationship between nominal interest rate differential and nominal exchange rate, for USD as home currency against the DEM, GBP, JPY, and the CAD. They used monthly rates of interest established in bond market rather than those in money market, for the period from 1980 to 1997.

The regression analysis revealed that nominal exchange rates are significantly related to nominal interest differentials in the cases of CAD-USD and JPY-USD. 
Siti and Eno (2009) regressed data for a five-years period (2003-2008) to test the validity of IFE between Indonesia (home country) and United States, Japan, Singapore, and the United Kingdom (foreign countries). Exchange rate change was taken as independent variable while interest rate differential was the dependent variable. They employed quarterly and yearly data and the results indicated that the difference in interest rates affects positively the exchange rate changes for United States, Singapore, and United Kingdom comparative to that of Indonesia; but that effect is not significant. However, the effect of interest rate differentials was negative and significant for Japan. This means that IFE held (although statistically insignificant) for United States, Singapore and UK pairing with Indonesia, whereas it didn't hold for Japan pairing with Indonesia.

For most empirical studies, the relationship between interest rate differential and exchange rates volatility relationship is not clear. This means that there may be some obstructions to foreign trade that may influence the adjustment of exchange rates apart from nominal interest rate differentials. Exchange rates can fluctuate due to other factors such as taxes, transaction costs, political risk, and strong country's monetary policy changes. These factors may prevent a free movement of capital between countries so that their nominal interest rate differentials can be compared (Emil, 2002; Salas, Andrea, \& Rodrigo, 2015).

\section{Research problem}

The capital mobility has affected currencies and interest rates of lowincome developing economies like those of East African Community where the level of exchange rate and its fluctuations determine the volume of exports, capital accumulation and growth (Ibrahim \& Raimundo, 2005). Exchange rates are sensitive to international capital movement (financial flows) and information. This movement depends upon various macroeconomic factors such interest rate, inflation rate, public debt, terms of trade, etc., among countries and can cause different pass-through effects in those countries that mostly rely on imports (Honohan \& Lane, 2003 \& 2004).

Since 1990s, East African Community countries experienced asymmetric inflation rates caused by various heterogeneities in the region based on relative productivity growth of tradable against non-tradable sectors (Simone \& Maxwell, 2017), and this has led to differences in interest rates across partner states.

The average inflation rate for the post-2000 period, is $9 \%$ in Burundi, $7.85 \%$ in Kenya, $6.45 \%$ in Rwanda, $7.43 \%$ in Tanzania, $6.87 \%$ in Uganda; with a dispersion of 0.88 (Jemma \& Anh, 2017). Combining interest rate differentials with exchange rate volatility is one of the factors that can 
contribute to the macroeconomic stability of the East African Community, as it can show the trend of the relationship between both variables.

Therefore, the central question in this study is based on whether nominal interest rate differential can be used to anticipate future exchange rate volatility among East African Community currencies. In other words, does a change in nominal interest rate differentials lead to the exchange rates volatility of East African Community currencies? If yes, in which direction?

\section{Objective of the study}

This study aimed at testing the effect of interest rate differentials on the exchange rate volatility of East African Community currencies for a period of five years starting from January 2013 to December 2017.

\section{Research methodology \\ Source of Data and Data collection Method}

The study used secondary data for all variables. Monthly exchange rates, money market interest rates, inflation rates, and current account balances of the five East African Community partner states such as Kenya, Uganda, Burundi, Tanzania and Rwanda were collected from reports of countries' Central Banks and national bureaus of statistics, World Bank and the International Monetary Countries' nominal interest rates, inflation rates and current accounts aided in computing interest differential, inflation differential and relative current account, by subtracting each foreign country values from the domestic country value.

\section{Analysis Plan}

To analyze the dataset, the study considered the following country pairs: Kenya/Tanzania, Kenya/Uganda, Kenya/Burundi, Kenya/Rwanda, Tanzania/Uganda, Tanzania/Burundi, Tanzania/Rwanda, Uganda/Burundi, Uganda/Rwanda, and Burundi/Rwanda. The focus was to test how the exchange rate among different currency pairs is affected by their nominal interest differentials. A panel data model was constructed, but before that, the study did a unit root test for stationarity through the estimation of Augmented Dickey Fuller (ADF) and Phillips-Person (PP) unit root tests, Levin, Lin and Chu test (LL), Im, Pesaran and Shin W-stat (IPS).

In this study, it is assumed a nonlinear relationship between the dependent variable and the explanatory variables and that the parameters are heterogeneous. By heterogeneity, it means that the parameters of the model are explicitly allowed to vary across country pairs.

Therefore, the model of this study was developed as follows:

$\mathrm{Y}_{\text {it }}=\alpha+\beta_{1}$ Int $_{\text {it }}+\beta_{2} \operatorname{Inf}_{\text {it }}+\beta_{3} \mathrm{Cab}_{\text {it }}+\varepsilon_{\text {it }}$ 
Where;

$\mathrm{Y}_{\text {it }}$ is the average monthly exchange rate between currency pairs $i$ at time $t$.

Int $_{\text {it }}$ is the nominal interest rate differential between home and foreign one month maturity T-bills $i$ at time $t$.

Inf $_{\text {it }}$ is inflation rate differential $i$ between home and foreign country at time $t$.

$\mathrm{Cab}_{\text {it }}$ is the relative current account balance $\mathrm{i}$ between home and foreign country at time $t$. The research was unable to find monthly publication on the Balance of Payments for Rwanda and Uganda. Therefore, Uganda quarterly current accounts were computed into monthly data, and Rwanda yearly current accounts were also computed into monthly basis.

$\alpha \quad$ is the intercept.

$\beta_{1}, \beta_{2}, \beta_{3}$, are the slope coefficients and they are all hypothesized to be positive. $\varepsilon_{i t} \quad$ is the error term.

\section{Model Results and Discussion}

\section{Unit Root Test}

In a unit root test, if the data is not stationary in level, it has to be differenced $d$ times to make it stationary and then series are said to be integrated of order (d) and represented as I(d).

Table 1: Unit Root Tests in Level (5\%)

\begin{tabular}{|l|l|l|l|l|l|}
\hline Variable & Description & LL & IPS & ADF & PP \\
\hline \multirow{4}{*}{ Exchange rate } & t-stat. & -2.726 & -1.404 & 33.77 & 20.89 \\
\cline { 2 - 6 } & Prob. & 0.0032 & 0.080 & 0.027 & 0.403 \\
\cline { 2 - 6 } & stationary & Yes & No & Yes & No \\
\hline \multirow{3}{*}{$\begin{array}{l}\text { Interest Differential } \\
\text { Inflation }\end{array}$} & Rate & -1.723 & -2.156 & 31.351 & 34.117 \\
\cline { 2 - 6 } \begin{tabular}{l} 
Differential \\
\cline { 2 - 6 }
\end{tabular} & Ptat. & 0.042 & 0.015 & 0.051 & 0.025 \\
\cline { 2 - 6 } & stationary & Yes & Yes & No & Yes \\
\hline \multirow{2}{*}{$\begin{array}{l}\text { Relative } \\
\text { Account }\end{array}$} & t-stat. & -2.206 & -2.473 & 34.642 & 34.684 \\
\cline { 2 - 6 } & Prob. & 0.013 & 0.006 & 0.022 & 0.021 \\
\cline { 2 - 7 } & stationary & Yes & Yes & Yes & Yes \\
\cline { 2 - 7 } & t-stat. & -2.121 & -3.594 & 52.02 & 53.014 \\
\cline { 2 - 6 } & Prob. & 0.016 & 0 & 0 & 0 \\
\cline { 2 - 6 } & stationary & Yes & Yes & Yes & Yes \\
\hline
\end{tabular}


Table 2: Unit Root Tests in First difference (5\%)

\begin{tabular}{|l|l|l|l|l|l|}
\hline Variable & Description & LL & IPS & ADF & PP \\
\hline \multirow{4}{*}{ Exchange rate } & t-stat. & -25.69 & -24.136 & 357.38 & 362.62 \\
\cline { 2 - 6 } & Prob. & 0.000 & 0.000 & 0.000 & 0.000 \\
\cline { 2 - 6 } & stationary & Yes & Yes & Yes & Yes \\
\hline \multirow{3}{*}{$\begin{array}{l}\text { Interest rate } \\
\text { differential }\end{array}$} & t-stat. & -17.93 & -18.75 & 298.76 & 306.42 \\
\cline { 2 - 7 } & Prob. & 0 & 0 & 0 & 0 \\
\cline { 2 - 7 } & stationary & Yes & Yes & Yes & Yes \\
\hline \multirow{3}{*}{$\begin{array}{l}\text { Inflation Rifferential } \\
\text { Date }\end{array}$} & t-stat. & -17.23 & -17.21 & 268.39 & 265.66 \\
\cline { 2 - 7 } & Prob. & 0 & 0 & 0 & 0 \\
\cline { 2 - 7 } $\begin{array}{l}\text { Relative Current } \\
\text { Account }\end{array}$ & stationary & Yes & Yes & Yes & Yes \\
\cline { 2 - 7 } & t-stat. & -16.11 & -22.05 & 338.99 & 405.81 \\
\cline { 2 - 7 } & Prob. & 0 & 0 & 0 & 0 \\
\cline { 2 - 6 } & Stationary & Yes & Yes & Yes & Yes \\
\hline
\end{tabular}

The results from table 1 and 2 indicate that not all series are stationary in level, but they are all stationary in first difference. This means that all series are then integrated of order one I(1).Therefore, the next step consists of continuing the analysis by deciding between the Fixed effects model and Random - effects model the one which can be considered as suitable model for the study. This is done through the Hausman test.

\section{Hausman Test}

Hausman test is a specification test to determine the best model to use between fixed and random models. These models differ from the correlation between individual effects and the explanatory variables. In panel data regression models, the fixed-effects model asserts that the specific effects can be correlated with explanatory variables. In the case of random-effects model, individual specific effects are random and cannot be added to the constant as dummy variables. These effects do not display any kind of correlation with the exogenous variables.

The two hypotheses of Hausman test are as follows:

$\mathrm{H}_{0}$ : Random-effects model is appropriate

$\mathrm{H}_{1}$ : Fixed-effects model is appropriate

When the probability value is statistically significant, fixed-effects model is used, otherwise we use the random-effects model. 
Table 3: Hausman Test Results

Correlated Random Effects - Hausman Test

Equation: Untitled

Test cross-section random effects

\begin{tabular}{|c|c|c|c|c|}
\hline \multicolumn{2}{|l|}{ Test Summary } & Chi-Sq. Statistic & Chi-Sq. d.f. & Prob. \\
\hline \multicolumn{2}{|l|}{ Cross-section random } & 16.063076 & 3 & 0.0011 \\
\hline \multicolumn{5}{|c|}{ Cross-section random effects test comparisons: } \\
\hline Variable & Fixed & Random & Var(Diff.) & Prob. \\
\hline INT & 0.027396 & 0.027658 & 0.000000 & 0.0001 \\
\hline INF & -0.007598 & -0.007490 & 0.000000 & 0.0035 \\
\hline $\mathrm{CAB}$ & 0.000052 & 0.000058 & 0.000000 & 0.0004 \\
\hline
\end{tabular}

The above table shows that the probability associated with the Chi-Sq. Statistic is significant (0.000). Therefore, we reject the null hypothesis, and the good model to use in this analysis is Fixed-Effects model.

\section{Estimation of Fixed - Effects model}

The regression results in the table 4 show that the adjusted coefficient of determination (Adjusted $\mathrm{R}^{2}=0.988$ ) is much greater than $50 \%$ which means that the variation of dependent variable (exchange rate) is explained by the independent variables taken together at $98.8 \%$. The probability of F-statistic is also significant (0.000).

Findings of this research show that all independent variables are statistically significant at the 5\% level. The intercept value showed that in any given month, the exchange rate between home and foreign currency will be 1.428 when all the predictor values are equal to zero.

The coefficient of interest rate differential is positive and significant which means that ceteris paribus, an increase by one unit of interest rate differential corresponds to an increase of 0.027 units in the exchange rate change of East African Community currencies. This means that a relatively high interest rate in home country leads to its currency depreciation.

In the same equation, results show that Inflation differential has a negative significant effect on the exchange rate. Even though this negative effect was not expected, the regression results showed that an increase by one 
unit of inflation rate differential corresponds to a decrease of 0.0075 units in the exchange rate change of East African Community currencies.

This means that when the home country inflation rate is relatively high, it will lead to the same country's currency appreciation, which contradicts the economic theory. Contrary to this result, the theory supports that coefficient sign of inflation should be negative because, an increase in inflation differential means that inflation rate is high in home country, and this would lead to home currency exchange rate depreciation.

Also, the relative current account has a positive and significant effect on the exchange rate. An increase by 1 unit of the relative current account deficit in home country corresponds to an increase of 0.000052 units in the exchange rate of East African Community currencies. Countries that import or spend more on foreign trade than what they export or earn from abroad, experience deficit current accounts. Consequently, it will need more foreign currency than it is getting from its exports. Excess of foreign currency demand decreases the home country's exchange rate (Taylor, 2001), thus the current account balance coefficient sign should be negative in our study.

\begin{tabular}{|c|c|c|c|c|}
\hline \multicolumn{5}{|c|}{$\begin{array}{l}\text { Dependent Variable: Y } \\
\text { Method: Panel EGLS (Cross-section random effects) }\end{array}$} \\
\hline \multicolumn{5}{|c|}{ Date: $20 / 01 / 19$ Time: $18: 30$} \\
\hline \multicolumn{5}{|c|}{ Sample: 2013M01 2017M12 } \\
\hline \multicolumn{5}{|l|}{ Periods included: 60} \\
\hline \multicolumn{5}{|c|}{ Cross-sections included: 10} \\
\hline \multicolumn{5}{|c|}{ Total panel (balanced) observations: 600} \\
\hline Variable & Coefficient & Std. Error & t-Statistic & Prob. \\
\hline $\mathrm{C}$ & 1.428333 & 0.026144 & 54.63299 & 0.0000 \\
\hline Interest differential & 0.027396 & 0.001774 & 15.44070 & 0.0000 \\
\hline Inflation differential & -0.007598 & 0.001681 & -4.520020 & 0.0000 \\
\hline Current account & $5.24 \mathrm{E}-05$ & $1.35 \mathrm{E}-05$ & 3.891519 & 0.0001 \\
\hline \multicolumn{5}{|l|}{ Effects Specification } \\
\hline \multicolumn{5}{|c|}{ Cross-section fixed (dummy variables) } \\
\hline R-squared & 0.988742 & & & \\
\hline Adjusted R-squared & 0.988512 & & & \\
\hline S.E. of regression & 0.146510 & & & \\
\hline F-statistic & 4296.105 & & & \\
\hline Prob(F-statistic) & 0.0000 & & & \\
\hline
\end{tabular}

\section{Conclusion}

The study analyzed the effect of interest rate differentials on the exchange rate volatility of East African Community currencies with specific 
country pairs such as between Kenya/Tanzania, Kenya/Uganda, Kenya/Burundi, Kenya/Rwanda, Tanzania/Uganda, Tanzania/Burundi, Tanzania/Rwanda, Uganda/Burundi, Uganda/Rwanda and Burundi/Rwanda. Average monthly interest rate differential, inflation differential, and relative current account balance, all information from January 2013 to December 2017 were considered for each country pair.

The study findings revealed a positive significant relationship between the exchange rate and two independent variables - nominal interest rate differential and relative current account balance. Ceteris paribus, an increase by 1 point in interest differential leads to an increase by 0.027 points of the exchange rate and a rise of 1 point in the relative current account corresponds to an increase of exchange rate by 0.000052 points. The implication of such conclusion is that in East African Community countries with relatively high interest rates will see their currencies depreciating and also countries with relatively high current account deficit will have depreciated currencies.

However, the study concluded that there is a negative significant relationship between exchange rate and inflation differential. This result contradicts the inflation differential theory given under the Purchasing Power Parity theory. In fact, the theory asserts that countries with relatively high inflation rates should see their currencies depreciating, which is different in this study case. The fact that Rwanda and Uganda do not publish the Balance of Payments' data on monthly basis might have affected the results adequacy.

In addition, East African Community countries have some differences whether economically, geographically, etc. It is reasonable for big country like Kenya to have a very high current account balance than Burundi. So, their current account differentials may bring some confusion about how it can affect the two countries' currency exchange rates.

In nutshell, more than $98 \%$ of the variation in the dependent variable was attributed to the three independent variables, and interest rate differential takes the main place to influence the exchange rate volatility as its coefficient $(0.027)$ is greater than the ones of inflation differential and relative current account balance.

\section{Recommendations for further research}

The study suggests that further research can be done on the same topic with other methodologies. This study assumed that there is no arbitrage in exchange rates among different countries which means that the spot exchange rate between two currencies was the same in home country and foreign country regardless other factors that be considered to adjust exchange rates.

Therefore, further research can be done by taking into account exchange rates as published by each central bank. In such perspective, the 
analysis can be doubled by considering each country as home and foreign country respectively.

The effect of interest rate differential on exchange rate can also behave differently if all country pair's data are regressed in a panel model and if each country pair is analyzed on its own. The significance may be different if variables are regressed from one country pair to another. Therefore, other studies can use other methods like Error Correction Model and regress separately the effect of interest rate differential on the exchange rate between Kenya and Tanzania, Kenya and Uganda, Kenya and Burundi, Kenya and Rwanda, Tanzania and Uganda, Tanzania and Burundi, Tanzania and Rwanda, Uganda and Burundi, Uganda and Rwanda, Burundi and Rwanda.

In addition, the study results showed that other factors apart from interest rate, inflation and current account balance affect the exchange rates in East African Community foreign exchange market.

Therefore it is envisaged that future scholars and researchers will investigate into details the effects of other elements like relative level of income, government control, relative employment rate, relative corruption index, relative tax rate, political situation, market judgment and speculation among others. The study further suggested that more research be carried out by changing the time frame of the analysis to deepen more information of literature on relationship between interest rate differential and exchange rate.

\section{References:}

1. Emil, S. (2002). An empirical investigation of the international fisher effect. Thesis, Lulea University of Technology. Social Science and Business Administration Programs.

2. Ersan, E. (2008). International fisher effect: a reexamination within the cointegration and DSUR frameworks. Thesis, Middle East Technical University. School of Social Sciences.

3. Fisher, I. (1930). The theory of interest. New York: Macmillan.

4. Francisco, N.D., \& Razzak, W.A. (1999). Nominal exchange rates and nominal interest rate differentials. International Monetary Fund, WP/99/141.

5. Furman, J., \& Stiglitz, J. E. (1998). Economic crises: evidence and insights from East Asia. Brooking Papers on Economic Activity 2, Washington D.C.

6. Hacker, S. R., Huynjoo, K., \& Kristofer, M. (2010). The relationship between exchange rate and interest rate differentials: a wavelet approach. CESIS. Paper No 217, The Royal Institute of Technology.

7. Honohan, P., \& Lane, P. R. (2003). Divergent inflation rates in EMU. Economic Policy, 18. 
8. Honohan, P., \& Lane, P. R. (2004). Exchange rates and inflation under EMU: an update. CEPR. Discussion Paper No. 4583.

9. Ibrahim, A., Elbadawi, \& Raimundo, S. (2005). Theory and empirics of real exchange rates in Sub-Saharan Africa and other developing countries. World Bank, Washington DC.

10. Jemma, D., \& Anh, D. (2017). Inflation convergence in East African countries. International Monetary Fund, Bank of Lithuania.

11. Lungu, W. (2014). The relationship between interest rate and exchange rate in Namibia. Journal of Emerging Issues in Economics, Finance and Banking, 3(1).

12. Salas, O., Andrea, G.M., \& Rodrigo (2015). Finding international fisher effect to determine the exchange rate through the purchasing power parity theory: the case of Mexico during the period 1996-2012. Applied Econometrics and International Development, 15(1), 98-110.

13. Sargent, T. J., \& Wallace, N. (1981). Some unpleasant monetarist arithmetic. Federal Reserve Bank of Minneapolis: Quarterly Review, 5: $1-17$

14. Simone, M., \& Maxwell, O. (2017). Exchange rate dynamics and monetary integration in the EAC countries. Toulouse School of Economics. Working Papers No 17-848. September.

15. Siti, R. U., \& Inanga, E. L. (2009). Exchange rates, interest rates, and inflation rates in Indonesia: the international fisher effect theory. International Research Journal of Finance and Economics, ISSN 1450-2887 Issue 26 (2009).

16. Stephen, S. M. (2014). The Effect of Interest Rate Differential on the Foreign Exchange Rate in East African Forex Market. Thesis, University of Nairobi.

17. Taylor, J.T. (2001). The Role of the Exchange Rate in Monetary Policy Rules. American Economic Review, Papers and Proceedings, 91, 263267. 